\title{
National Governance Capacity from the View of Comparative Political Economy - Based on the Fight Against COVID-19
}

\author{
Wentao Yao ${ }^{*}$, Gang Wang2 \\ 1Jingyan Education Technology Co., Ltd., Beijing 100871, China \\ ${ }^{2}$ Shangmei Middle School, Jiujiang 332000, Jiangxi Province, China \\ *Corresponding author: Wentao Yao, 574582029@qq.com
}

\begin{abstract}
At the beginning of 2020, COVID-19 has blocked the pace of the world economic development. In the process of fighting the epidemic, different countries have formulated different policies and showed different effects from fighting it. After the end of COVID-19, the rapid social and economic recovery as well as their development require scientific and effective governance from all countries. From the perspective of comparative political economy theory, taking the COVID19 epidemic as an example, this article points out the advantages and deficiencies of the national governance capacity, as well as seek ways to improve the national governance capacity.
\end{abstract}

Keywords: Politics and economy; COVID-19; Governance; Capacity

Publication date: August 2021; Online publication: August 30, 2021

\section{Research background}

In 2020, China completed the building of a moderately prosperous society in all respects. The sudden occurrence of COVID-19 caused an impact on the construction and development of the progress in China and the world. However, the Chinese government has always been people-centered; they formulated scientific policies, implemented strict prevention and control measures, and quickly resumed work as well as production. In contrast, the U.S. government was slow to address the epidemic; making the deaths evolved into a "government-approved Holocaust campaign." This article explores the capacity of the national governance from the perspective of comparative political economy theory. In different periods, countries have always been the focus and research subjects because of different developments, leading to the causal discussion on national development to explore how countries should manage economic affairs by comparing the relations between the governments, markets, and interest groups from different countries [1].

\section{Advantages of national governance from the perspective of comparative political economy based on the fight against COVID-19}

After the outbreak of COVID-19, China, under the unified leadership and coordination of the central government, quickly mobilized medical personnel and medical supplies across the country to support the worst hit areas by the epidemic. In March, 8,346 medical teams arrived in Wuhan and Hubei, with a total of 42,600 cases. China's successful fight against the epidemic benefits from the advantages of the Chinese characteristics (treatment with integrated traditional Chinese medicine and western medicine). Meanwhile, mass demonstrations in the stock market collapsed. The United States government was in sharp contrast 
with the positive actions of the Chinese government, further proving the flaws of the attachment theory which emphasizes the decisive role of the international economic system on the internal political and economic structure as well as the relations of developing countries. The advantages of China's independent national governance are reflected as follows:

\subsection{Nationalist paradigm highlights the superiority of the socialist system with Chinese characteristics}

The nationalist paradigm centers on state-social relations and believes that the state acts independently in addition that the conscious and unconscious micro-intervention in the economy and society can play a role in promoting economic development as well as highlight the role of the state. According to the law, China incorporated COVID-19 into Class B infectious diseases stipulated in the Law of the People's Republic of China on the Prevention and Control of Infectious Diseases and took measures to prevent as well as control Class A infectious diseases. At the same time, it did a good job in international and domestic laws which reflects the advantages of China's political system. With that, the number of cases dropped sharply (Figure 1), and the epidemic was under effective control. The epidemic still rages on in the United States under Trump's administration.



Figure 1. Confirmed cases of COVID-19 in China

\subsection{Post-development theory - China made significant progress in science and technology}

According to the post-development theory, the later the development, the more the challenges, and the more the organizational institutions need to intervene. After the reform and opening up, the Chinese government, as a strong organization, focused on the development of aviation and other high-tech industries related to people's livelihood where the country's comprehensive strength and governance capacity greatly improved. The modern war against the epidemic is a scientific and technological war whereby scientific and technological breakthroughs should race against the virus. Virus detection, transmission, screening of treatment drugs, and the formulation of treatment programs should all run ahead of the virus ${ }^{[2]}$. China has taken the lead in developing the COVID-19 vaccine, which has not only made significant progress in medicine, but also as an important research result in public health, public management, emergency management, and other disciplines. 


\subsection{Social union paradigm - progress of the Chinese people and enterprises improves national governance capacity}

The capacity of national governance is mainly reflected in the country's policy formulation and implementation, mobilization and organizational, crisis response, their own management ability, as well as other aspects. The social union paradigm states that the state and the society are not independent of each other, but a cross-union and struggle between interactive national and social components driven by different interests. Policy is driven by a social union between the state and the society. China's victory in the fight against the epidemic is the result of the joint role of the government, people, and enterprises. The evolution process of a Chinese-style government-market relation enriches the theory of market economy diversity and reveals the path to continuously achieve independent development under the contemporary international division of labor ${ }^{[3]}$. In short, the progress of the Chinese people and enterprises have improved the country's governance capacity.

\section{Deficiencies of national governance from the view of comparative political economy based on the fight against COVID-19}

COVID-19 exposed the lack of countries' governance capacity in different fields such as the pre-warning mechanism for sudden infectious diseases whereby it is not scientific enough, organizational structure, imperfect job design, unscientific distribution of rights and responsibilities, unreasonable personnel administration, as well as other issues.

\subsection{Mismatch of financial power and authority between the central and local governments causing the crisis of local government governance}

Governance is a process of continuous interaction involving the coordination between the public sector and private sector ${ }^{[4]}$. During the epidemic outbreak, the public and private sectors in the United States were not able to provide enough protective clothing, masks, goggles, and other equipment, in addition, the public service system was facing collapse. This reflects the mismatch of the power between the central and local governments which caused a local government governance crisis. For example, Wuhan, in the Hubei Province, lacks financial funds and it needs support from the central government as well as donations from all walks of life. The market mechanism alone cannot solve this problem. The invisible hand of the market requires a visible hand to create ${ }^{[5]}$. Therefore, the government should use and support the financial and personnel administrative systems as a breakthrough point in reforming and improving coordination so that the government and the public have solid ability, as well as supporting rights and responsibilities to carry out work and solve problems in a short period of time.

\subsection{Problems in the standards of government assessment with the constant need to deepen reform}

Comprehensively deepening reform is largely the reform of the national governance system in which the purpose is to improve China's governance capacity, optimize the national governance structure, and establish a modern national governance system ${ }^{[6]}$. In the traditional society, national ability mainly comes from the state's ability to penetrate the society and to absorb resources whereas in contemporary countries with strong social forces, they often promote economic development by constantly adjusting economic intervention and strengthening cooperation with the society. Therefore, the lack of government and Party cadres at all levels of scientific achievements as well as with the theory of GDP only, the pursuit of political achievement projects and image projects are not conducive to the development of the economy and enterprises along with serious problems in the government assessment standards. 


\subsection{Lacking supporting institutional arrangements in crisis governance}

Professor Yang Kaifeng elaborated the eight logics of national governance from the institutional perspective as shown in Figure 2. Crisis governance is a part of national governance. According to these eight logics, China lacks supporting institutional arrangements in four aspects which include the slowdown, preparation, response, as well as the recovery and reconstruction of crisis management. It can optimize the system formulation and implementation, the coordination between the upper and lower levels, and the unity of theory and practice.



Figure 2. Eight logics of Chinese national governance

\section{Ways to improve the national governance capacity}

\subsection{Using the theory of interest to solve the dilemma of democratic governance}

In the process of fighting against the epidemic, policy decision makers use market prices and interest rates as a "coordination" signal between decisions to motivate the public to produce and manufacture public goods that the people need. Gree Group, for example, has turned to produce face masks. Robert Dahl, in Democracy and Its Critics, once stated that the ideal democratic order is first required to meet the conditions in which the interests of the citizens must be harmonious enough to enable them to share and act in a strong sense of universal good that does not significantly conflict with the goals or interests of the individual. There must be a high degree of homogeneity among citizens or political conflict and distinct differences over public good. From the perspective of interests, there is a need to establish the correct concept of development and achievements, carry out supporting reforms, change government duties from control and management to service as well as governance.

\subsection{Improving the structure of organizational powers and responsibilities as well as the capacity of the country}

At the international level, a strong country refers to strong military, politics, and economy whereas at the domestic level, a strong country means high national autonomy. From the national point of view, national sovereignty and territorial control are prerequisites for national capacity, while stable bureaucracy and 
adequate economic resources are the fundamentals of national capacity. From a social perspective, national capacity depends on how much social support it can obtain with the concentration of social forces in different policy areas and the support for national policy. The central government should further delegate power especially to professional science and technology as well as medical departments in addition to confer the right to give early warnings of an epidemic with unknown causes by health administrative departments of provincial governments. With equal powers and responsibilities, the responsibilities would be assumed and in turn, improve the capacity of the country.

\subsection{Building a legitimate government with public credibility}

The people's trust toward the government is the real source of its legitimacy. The reasons for weakening government credibility are as follows:

First, the failure of the government would reduce the citizens' trust in the government. Government officials should recognize "government failure" which is mainly manifested in high cost, separation of cost and income, internal problems, low efficiency of government organizations, rent-seeking, inefficient policy implementation, etc. Second, the relevant legal systems in the field of national governance are imperfect. The chaos of the society in Hong Kong is a reflection of the state's poor governance under the "one country, two systems" governance. In addition, under the influence of the traditional "official standard" concept, the government pays too much attention to the pursuit of its own interests, imperfect construction of government integrity system, supervision, and restriction mechanism of government integrity, asymmetry and opacity of government information, as well as a poor sense of integrity among government officials.

\section{Conclusion}

Based on COVID-19, this article analyzes the advantages and deficiencies of national governance as well as the ways to improve the governance capacity. Although there is no perfect universal government in the world, the construction of a clean, honest, efficient, legal, and capable government is the requirement of the times and the people. In parts, the worst corruption is the incompetence of the government ${ }^{[7]}$. A healthy society is a society where good people and good officials interact. Therefore, expand the role of citizens in national governance, give full play to the role of the government, community, and "shadow government" media organizations, make policies scientific, legitimate, and effective, give full play to their advantages, make up for their shortcomings, improve China's governance capacity, as well as realize the modernization of national governance.

\section{Disclosure statement}

The authors declare that there is no conflict of interest.

\section{References}

[1] Yan J, 2020, System, Policy and Efficiency: System Advantages and Efficiency Transformation of China. Political Science Studies, (2).

[2] Zhang D, et al., 2020, Feasibility and Suggestion of Promoting Pulmonary Function Examination Technology in Primary Health Care Institutions. Chinese General Practice, 29.

[3] Song L, Xie Y, 2019, The Evolution Process and Theoretical Significance of Chinese-Style Government - Market Relations: The Perspective of Industrial Policy. Journal of the Party School of the CPC Central Committee (National School of Administration), 23(01): 123-8.

[4] Yu K, 2001, Governance and Governance: A New Framework for Political Analysis. Nanjing Social 
Sciences, (9).

[5] Zhou Z, 1998, Theoretical Thoughts on the Optimization of Chinese Government Function Modernization, Peking University Press.

[6] He Z, 2014, Accurate understanding of National Governance and its Modernization. Theoretical View.

[7] Zhang C, Dang X, 2012, Public Management, Renmin University of China Press, Beijing, 353.

[8] 2014, Selection of Important Documents since 4, 18th National Congress, Central Literature Publishing House, Beijing, 309.

[9] Xi J, July 2, 2016: Speech at the 95th Anniversary of the Communist Party of China. People's Daily. 